\title{
Proposal for a Common Currency among Rich Democracies
}

Richard N. Cooper

Harvard University

\section{The Proposal}

This paper suggests that some time in the not-too-distant future the governments of the industrialized democracies - concretely, the United States, the European Union, and Japan - should consider establishing a common currency for their collective use. A common currency would credibly eliminate exchange rate uncertainty and exchange rate movements among major currencies, both of which are significant sources of disturbance to important economies. One currency would of course entail one monetary policy for the currency area, and a political mechanism to assure accountability. This proposal is not realistic today, but is set as a vision for the second or third decade into the $21^{\text {st }}$ century. Europeans, in creating EMU, have taken a major step in the direction indicated. Their idea could be taken further.

\section{How Would a Common Currency Work?}

The following paragraphs sketch how the common currency might be constituted, how it might be expected to function, and how it might be reached. The key components to a common currency area would be the United States, the members of the European Economic and Monetary Union (EMU), Japan, and probably the United Kingdom (which might by time of adoption in any case be a member of EMU). These countries constitute the core of the international monetary system, and are likely to do so for decades to come. They all have high incomes and similar structures of demand and output. Canada, Australia, New 
Zealand -- indeed any of today's 30 members of the Organization for Economic Cooperation and Development (OECD) -- would be welcome to join, although for reasons given below becoming full members might be unwise. Members must have democratic governments, to ensure legitimacy. Other countries could, at the initiative of each, link their currencies to the key currency. The common currency could be given any name that commanded wide acceptance -- e.g., bancor (the name suggested by Keynes for his international central bank currency), crown, dirham (the name of the major Roman unit of currency), or ena (for europe-nippon-america). The common currency might, but need not, imply common banknotes for ordinary circulation. Member countries could continue to circulate banknotes containing national symbols, just as (before introduction of the new, hard-to-counterfeit higher-denomination bills) Federal Reserve notes within the United States could be separately identified with the twelve Reserve banks of issue, and even with different names. Euro coins also contain different national symbols. The central point is that they would be fully convertible into one another at a rigidly fixed exchange rate, and electronic payments would all take place in the common currency.

One currency requires a single monetary policy. Monetary policy could be made by a Board of Governors, made up either of pre-existing central bank governors (existing central banks would continue as branches) or of individuals appointed to long terms for their knowledge and probity, or of some combination of the two. If it were made up of governors of the national central banks alone, votes would be apportioned according to GDP, updated at regular intervals.

The Governing Board would decide monetary policy throughout the currency area. But it needs to be made politically accountable, a serious deficiency (in my view) with the 
current arrangements of Europe's EMU, where the ECB must report to the Europoean Parliament, but the latter body can take no effective action with respect to monetary policy. Only amendment of the Maastricht Treaty, requiring unanimity among all European Union members, can do that. In contrast, the US Federal Reserve, while independent of the executive branch of government, is not independent of the political process, hence political accountability, since its statutes are determined by simple legislation, which could be altered through the normal legislative process. The same was true of the German Bundesbank before its absorption into the framework of the EMU. A supra-national parliament is not required, however, to make the Board of Governors accountable. Its decisions could be over-ruled by a heavy (e.g. 70 percent) vote of national governments as represented by ministers of finance, with votes apportioned by GNP, who are ultimately accountable to parliaments. Such action would presumably be rare, but if in the collective judgement of governments the Board of Governors was pursuing grossly inappropriate actions, its actions could be countermanded. This possibility would itself likely be sufficient to keep monetary policy within the bounds of public acceptability.

The objective of monetary policy should be to maintain "stability of the currency," an artful phrase drawn from the statutes of the German Bundesbank, which leaves somewhat more latitude than the primary charge of the Maastricht Treaty to the European Central Bank to maintain "price stability." The Board of Governors should also look after the soundness and smooth functioning of the financial system, a responsibility erroneously not given to the ECB, acting as appropriate as a lender of last resort. And of course it should cooperate with governments in the pursuit of their general macro-economic objectives. 


\section{Rationale for the Proposal}

Flexible exchange rates have obtained since 1973 among the major currencies of the world: the US dollar, the Japanese yen, the British pound, the Canadian dollar, and the continental European currencies centered around the German mark. In contrast to what Nurkse(1944) might have expected, the experience has not been a disastrous one, and indeed arguably floating exchange rates helped their economies navigate more smoothly among some major world disturbances, such as the oil price shocks of 1974, 1979-80, and 1986 and the German unification of 1990. On the other hand, some have argued that because world oil prices are denominated in dollars the three oil shocks themselves were caused by sharp movements in dollar exchange rates. While I find this implausible, the fact that the case can be put forward suggests the complexities of cause and effect when it comes to currency arrangements and their impacts on real economies.

Nominal and real exchange rates also responded strongly to the "fiscal twist" of the early 1980s, when the United States pursued an expansionist fiscal policy while Britain, Germany, and Japan, later joined by France, pursued contractionary fiscal policies. Whether one assesses the consequential sharp appreciation of the dollar in the early 1980s as benign or malign, it certainly had real and durable effects not only on foreign trade but also on the structure of output, not least because of high fixed costs sometimes associated with product entry into a national market (as emphasized by Krugman, 1989). Arguably the depth and duration of Japan's recession in the 1990s can be explained in part by excessive exchangerate-induced industrial expansion in Japan in the mid-1980s, when the cheap yen made Japanese goods highly competitive in the American market. 
More recently, the dollar-yen exchange rate reached 85 yen per dollar briefly in 1995 and then moved to $145 \mathrm{yen} / \$$ briefly in 1998 , a swing of 70 percent over three years (and back to 108 yen/\$ by early 1999). The USA and Japan were both successfully pursuing low inflation monetary policies (Japan at 1 percent, USA at 2.3 percent increase in the consumer price index per year). What then justifies a swing of this magnitude? What disturbance does it create for trade (e.g. in stimulating anti-dumping suits by US firms) and for investment planning -- not only for exports, but for a domestic market subject to import competition? What disturbance does it create for balance sheets, especially of financial institutions? How many economically sound firms were thrown into bankruptcy? Might the prolonged recession in Japan -- including extensive overseas investment by Japanese firms -- be related in part to fear of wide swings in exchange rates? Are they hedging against future exchange rate uncertainty by diversifying their production across currency zones, especially into Europe and into North America? Exchange rate movements of this type certainly violate the expectations and contentions of advocates of floating rates in the 1960s (e.g., Johnson) and they cannot signify well-functioning international monetary arrangements.

The euro also went through some gyrations after its introduction in January 1999. It started at $\$ 1.17$ per euro, fell eratically to $\$ .83$ in the fall of 2001 , and subsequently rose to briefly to $\$ 1.38$ in late 2004 - a swing of 66 percent - before settling into the $\$ 1.20-1.30$ range during 2005. Surely one of the factors inhibiting investment in Europe and Japan in recent years is the prospect -- some would say the certainty -- that in the not-too-distant future the euro and the yen will appreciate substantially against the US dollar, nullifying any calculations of profitability made at today's exchange rates. 
We should note another potential source of disturbance: the creation of the euro out of ten pre-existing currencies in early 1999. A number of economists (e.g. Bergsten(1997, 1999), Masson and Turtelboom(1997), Portes and Rey(1998)) have suggested that exchange rate volatility between the dollar and the euro may well be higher than it was between the dollar and the German mark before 1999. The reasons are partly structural -- euroland is much more self-contained than the individual countries were, so exchange rate variation will cause fewer internal disturbances, hence fewer calls for action to stabilize exchange rates; and partly institutional, since the newly created European Central Bank is charged with pursuing price stability, not stabilizing currency values. Thus the ECB need pay attention to exchange rates only insofar as their movements threaten price stability, and pronouncements by the ECB indeed indicate relative indifference to the dollar-euro exchange rate, except for several interventions in the fall of 2001, when the euro had depreciated extraordinarily.

This greater volatility could be greatly aggravated if during the next decade foreign exchange holders around the world decide to switch their claims substantially from US dollar-denominated ones to euro-denominated ones, as some have suggested will occur (e.g. Bergsten (1997), Portes and Rey (1998)). I have argued elsewhere (Cooper, 1999) that a rapid large-scale switch from dollars to euros is not likely to occur because of the absence of sufficient suitable euro-denominated securities, and that growing internationalization of the euro will occur more gradually and smoothly in a context of world economic growth. But if a rapid switch does occur, it is likely to take place in several episodes rather than all at once, leading to episodic depreciation of the dollar, but at a rate and to an extent that is impossible to predict, since the potential for such switching will be seen to be very large. 
Exchange rates are increasingly determined by financial transactions, which overwhelm trade and other current transactions in their magnitude. Financial transactions are subject to bandwagon effects, as each player seeks to be ahead of others in the market, and institutional investors seek performance that does not deviate negatively from performance of their peers. Yet the erratic exchange rates determined by such behavior also govern international trade. Particular trade transactions can be financially hedged in the short run, at a cost; but investment for the purpose of engaging in trade cannot be similarly hedged. The result is likely to be both too little total investment, and too much investment in the wrong places, driven by the need of firms to hedge by locating within each major currency area, even if economic efficiency would be better served by locating elsewhere and importing. Furthermore, sustained misalignment of exchange rates is likely to increase protectionist pressures, as it did in the United States during the mid-1980s and in Europe during the early 1990 s.

In short, movements in exchange rates, while providing a useful shock absorber for real disturbances to the world economy, are also a substantial source of uncertainty for trade and capital formation, the wellsprings of economic progress. Whatever benefits flexible exchange rates may provide as a shock absorber, and they are real, will be increasingly dominated and eventually overwhelmed by the costs of flexible exchange rates as a generator of economically unjustified shocks to productive activity. This worsening costbenefit ratio makes a case for a common currency among the world's major economies. A common currency at the core of the world economy will also make easier the management of exchange rates by other countries. 


\section{The Adjustment Mechanism}

How would the adjustment process work with such a scheme in place? How often would it have to work? Asymmetrical real disturbances leading to payments imbalances would of course lead to monetary contraction in regions experiencing negative shocks, and to monetary expansion in regions experiencing positive shocks. Those changes alone would lead to economic contraction and economic expansion, respectively. The possibility of economic contraction in response to negative shocks leads many economists to prefer flexible over any form of fixed exchange rate. Several important mitigating circumstances need to be mentioned.

First, Europe, Japan, and the United States are all large, highly diversified, open economies, so the likelihood is low that asymmetrical shocks would affect them differentially in a quantitatively significant way. Shocks for each region as a whole are likely to be diversified, and largely offsetting. (It is this factor that leads to some doubts about the inclusion of countries such as Australia or New Zealand, with their relatively high dependence on exports of primary products. But a decade or two hence they may be more highly diversified.)

Second, asymmetrical monetary shocks will virtually disappear with a common currency; that indeed is the point of the proposal. Neither diverse monetary policies nor diverse expectations about future movements of exchange rates would create adjustment problems among the participating regions, as they do now and will increasingly do in the coming years. These translate into real shocks through the movement of real exchange rates, a source of asymmetrical real disturbance that would be eliminated under the proposal. 
Third, such asymmetrical real shocks as might occur can be mitigated by offsetting fiscal action, focussed on non-tradable goods. Governments would not of course have direct access to the common Monetary Authority; but they would have access to a broad capital market covering all of the participating countries.

Fourth, real wages could if necessary, over time, move down as well as up, since monetary policy focussed on the producer price index (see below) would leave room for differential movements in consumer prices. An international regime in which monetary authorities all successfully stabilize consumer prices requires long-run flexibility in exchange rates so long as nominal wages are inflexible downward, as they seem to be. Anchoring monetary policy in stable producer prices would avoid this implication.

\section{Implications for Non-Members}

Few countries of the world either have or desire freely floating exchange rates. Many fix their currency to some leading currency (or a basket of them); others allow market flexibility but intervene in the foreign exchange market to guide market expectations and to influence the exchange rate. Floating exchange rates among major currencies creates both a policy problem and an operational problem for these countries. The policy problem is to decide to which of the major currencies (or what combination of them) to orient the currency in question, and the operational problem is to choose a currency in which to engage in market intervention. These problems would not be acute if the major currencies did not move significantly against one another, and if such movements as did take place reflected mainly inflation differentials among the major countries, as was thought to be the

case by advocates of flexible exchange rates in the 1960s (e.g., Johnson). But major 
currencies have in the past decade experienced major swings against one another, creating serious problems for some, perhaps many, third countries in their exchange rate management. One of the advantages of a common currency in the core of the world economy is that countries could confidently frame their exchange rate policies with respect to this common currency - either fixing to it, if that seemed best, or maintaining a managed float against it. It would provide monetary stability for the world economy.

Many countries, including some eligible to join the common currency (e.g. Australia), might find it advantageous not to do so. The more specialized an economy, especially in its foreign trade, the more subject it would be to asymmetric shocks, and the more useful might be a separate currency with its own exchange rate to provide a shock absorber in such situations. Each eligible country would decide for itself where the balance of costs and benefits lay, and of course this calculation might change over time.

\section{Transition: Getting from Here to There}

McKinnon (1984, 1996) has proposed an alternative, but not entirely dissimilar, arrangement between Germany, Japan, and the United States (EMU could easily be substituted for Germany). Concretely, as applied to Japan and the USA (see McKinnon and Ohno, 1997), the proposal involves determining a target exchange rate based on purchasing power parity of wholesale (not retail) prices and establishing a permissible band of 10 percent around this rate, with soft edges. The width of the band would be narrowed over time, as confidence in the system grew. Monetary policy in both countries would be keyed in the long run to stabilizing the respective domestic wholesale (in the US, producer) price indices. Concerted market intervention would attempt to keep exchange rates within the 
permissible band, but such intervention would not be completely sterilized, to allow exchange rate intervention to influence domestic monetary conditions.

Wholesale prices are dominated by tradable goods, and lack domestic sales taxes and retail mark-ups. They also exclude services. Thus there should be a high correlation in the movement of British, European, Japanese, and American wholesale prices, such that monetary policy in each entity would be targeted on roughly the same price index. If they were successful, inflation rates measured by consumer prices in these regions would differ for a variety of reasons (e.g., changes in sales tax rates, greater competition in retail trade, changes in mix of services consumed and in prices of services), but such differences would presumably have little impact on international trade. Stability in wholesale prices would anchor monetary policy. Since price stability in wholesale prices would lead to some inflation measured in consumer prices, that would introduce some flexibility for adjustments in real wages in the face of nominal wage rigidity, thus facilitating adjustment to shocks both within and between economies. Stability in consumer prices, in contrast, introduces relative price rigidity in the presence of downward price inflexibility, which is widely observed, and thus impedes adjustment.

As an interim process for getting from here to the common currency, the prospective members could adopt the Keynes/McKinnon approach, described above, of targeting monetary policy on stabilizing national indices of producer prices. With low trade barriers these will be made up mostly of tradable goods competitively linked through foreign trade (some agricultural products are today the major exception, but even agricultural trade may be more liberalized after another round or two of multilateral trade liberalization). Over time, the indices could be brought into close direct correspondence, even be made formally 
identical. International consultation and even coordination could take place over when (if ever) particular price movements might be excluded, e.g. an exceptional rise in world oil prices. (Indeed, prices of all crude materials might be excluded from the targeted index from the start.) Success in stabilizing closely related price indices in the participating regions should lead to medium run convergence of exchange rate expectations.

\section{Conclusion}

The proposal for a common currency among the large industrial democracies draws its rationale from three empirical prognosications. The first is that international financial transactions will continue to grow relative to international trade in goods and services, and that financial factors will come to dominate exchange rate determination even more than they do today. At the same time, the exchange rate will become even more important, as economies integrate further, in determining the profitability of trade and investment than it does today.

The second prognostication is that real shocks among these large economies will not be radically asymmetrical. Because they are large and diverse, disturbances within these economies are likely to be more important than disturbances between them, and adjustment to such shocks will be no more difficult, and perhaps easier, than adjustments to shocks within these economies.

The third prognosication is that financial markets will be just as fickle in the future as they have been in the past. That is to say, they will continue to fail to satisfy Harry Johnson's contention that they are far-seeing and universally stabilizing in their behavior. 


\title{
Under these circumstances, by eliminating monetary and exchange rates as
}

\author{
sources of asymmetric shocks among the participating countries, a common currency will \\ conduce to more stable economic activity and possibly higher growth.
}

\section{Endnotes}

\begin{abstract}
- Under anti-dumping regulations agreed in the Uruguay Round, a firm whose home currency has appreciated must adjust its foreign prices to the change within 60 days to avoid being charged with dumping; de minimus margins for dumping, including "dumping" produced by changes in exchange rates, are only two percent. In short, the anti-dumping rules expose normal business practice of list pricing to foreign customers to protectionist action in the presence of routine movements in exchange rates.

- Gros (1999) is more skeptical that dollar-euro exchange-rate volatility will be higher than pre-1999 dollar-DM volatility.

- In discussing international coordination of policies Keynes (1930) suggested that all major countries target the same index of prices of a basket of internationally traded commodities, ranging from aluminum to zinc. Concretely, writing under a gold standard, he suggested adjusting the official conversion price of gold periodically to maintain its value in terms of an index of 62 commodities -- the equivalent of targeting price stability of the index.
\end{abstract}

\section{References}

Bergsten, C. Fred, 1997, "The Dollar and the Euro," Foreign Affairs, 76 (July/August)

Cooper, Richard N., 1984, "A Monetary System for the Future," Foreign Affairs, (fall), 166-184.

Cooper, Richard N., 1999, "Key Currencies after the Euro," The World Economy, 22 (January), 1-23.

Gros, Daniel, 1999, "Global Exchange Rate Stability after the Introduction of the Euro," The Euro and the New International Financial Order

Johnson, Harry G., 1969, "The Case for Flexible Exchange Rates, 1969," reprinted in Further Essays in Monetary Economics, Cambridge, MA: Harvard University Press.

Keynes, J.M., 1930, A Treatise on Money, vol. 2, London: Macmillan.

Krugman, Paul, 1989, Exchange-Rate Instability, Cambridge, MA: MIT Press.

League of Nations (Ragnar Nurkse), 1944, International Currency Experience, Geneva: League of Nations.

Masson, Paul, and Bart Turtelboom, 1997, "Transmission of Shocks under Emu, the Demand for Reserves and Policy Coordination," in Masson, Paul R., T.H. Krueger, and 
B.G. Turlelboom, eds., EMU and the International Monetary System, Washington: International Monetary Fund.

McKinnon, Ronald I., 1984, An International Standard for Monetary Stabilization, Washinton: Institute for International Economics.

McKinnon, Ronald I., 1996, The Rules of the Game: International Money and Exchange Rates, Cambridge, MA: MIT Press.

McKinnon, Ronald I., and Kenichi Ohno, 1997, Dollar and Yen, Cambridge, MA: MIT Press.

Portes, Richard, and Helene Rey, 1998, "The Emergence of the Euro as an International Currency," Economic Policy (April), 307-343. 